\title{
KETAHANAN STRUKTUR GEDUNG EVAKUASI DI DESA LAMBUNG TERHADAP BEBAN TSUNAMI
}

\author{
Sherlya Wahyuni ${ }^{1}$ Yunita Idris $^{1}$ Syamsidik $^{2}$ \\ ${ }^{1}$ Jurusan Teknik Sipil, Universitas Syiah Kuala, Banda Aceh 23111, Indonesia \\ ${ }^{2}$ Jurusan Teknik Geologi, Universitas Syiah Kuala, Banda Aceh 23111, Indonesia. \\ Email: \\ wahyunisherlya.sw@gmail.com
}

\begin{abstract}
Banda Aceh is an area with high potential for earthquakes and tsunamis, therefore it is necessary to build a vertical evacuation building (TES) that can with stand the burden of the earthquake and tsunami so as to minimize future victims. The vertical evacuation building in the hull was built in 2006, at that time the construction of the building used SNI 1726: 2002 and did not take into account the tsunami load in its construction. One way to identify whether the building is still safe from earthquake loads according to SNI 1726: 2012 and safe from tsunami loads according to FEMA P-646 is to re-model the building based on the results of technical data obtained through direct measurements in the field using SNI 1726: 2012. The object of research is Escape Building in Lambung Village, Banda Aceh. The results of this identification show that the highest displacement value of $x$ and $y$ direction due to earthquake load is 0,016235 m and 0,05852 m, while displacement due to the biggest tsunami load in $x$ and $y$ direction is 0,00837 $\mathrm{m}$ and 0,28836 $\mathrm{m}$. It can be seen that the biggest displacement is due to the tsunami load.
\end{abstract}

Keywords: Lambung Village evacuation building, tsunami load, structural strength, FEMA P646, SAP2000 Software

\begin{abstract}
Abstrak
Banda aceh merupakan daerah yang berpotensi tinggi terhadap terjadinya gempa dan tsunami, oleh karena itu perlu adanya pembangunan tempat evakuasi sementara (TES) yang dapat menahan beban gempa dan tsunami sehingga dapat meminimalisir korban yang akan datang. Gedung evakuasi di lambung telah dibangun pada tahun 2006, pada saat itu pembangunan gedung menggunakan SNI 1726:2002 dan belum memperhitungkan beban tsunami didalam pembangunannya. Salah satu cara untuk mengidentifikasi apakah gedung tersebut masih aman terhadap beban gempa menurut SNI 1726:2012 dan aman terhadap beban tsunami menurut FEMA P-646 yaitu dengan memodelkan kembali gedung tersebut berdasarkan hasil data teknis yang didapat melalui pengukuran langsung dilapangan menggunakan SNI 1726:2012. Objek penelitian yaitu Escape Building Desa Lambung, Banda Aceh.. Hasil dari identifikasi ini didapat nilai displacement terbesar arah $\mathrm{x}$ dan y akibat beban gempa adalah 0,016235 $\mathrm{m}$ dan 0,05852 $\mathrm{m}$, sedangkan displacement akibat beban tsunami terbesar arah $\mathrm{x}$ dan y adalah 0,00837 $\mathrm{m}$ dan 0,28836 m. Dapat dilihat bahwa displacement terbesar akibat beban tsunami.
\end{abstract}

Kata kunci : gedung evakuasi Desa Lambung, beban tsunami, kekuatan struktur, FEMA P646, Software SAP2000

\section{Pendahuluan}

Indonesia adalah kepulauan yang terletak pada empat lempeng tektonik, pergeseran lempeng tektonik yang terjadi merupakan pemicu terjadinya tsunami. Selain itu, aktivitas vulkanikpun menjadi pemicu lainnya. Tsunami aceh yang terjadi pada 26 desember 2004 merupakan bencana tsunami yang banyak mendapat perhatian. Besarnya korban jiwa dan kerugian ekonomi menjadi bukti bahwa bangsa Indonesia belum siap dalam mengantisipasi bencana tersebut. Sejak tahun $416 \mathrm{M}$ sampai 2018 tsunami itu sendiri telah terjadi sebanyak 246 kali di Indonesia. (NOAA)[1].

Pembangunan gedung evakuasi semnetara merupakan fasilitas publik yang berfungsi sebagai fasilitas publik yang berfungsi sebagai tempat evakuasi sementara bilamana terjadinya tsunami. Idealnya bangunan ini ada di setiap wilayah pesisir pantai dengan

Journal of The Civil Engineering Student

Vol. 3. No. 2, Agustus 2021, Halaman 183-189 potensi bencana tsunami dan padat penduduk. Di Banda Aceh terdapat empat gedung evakuasi vertikal yang

kokoh yaitu Escape Building di Desa Lambung, Gedung Evakuasi Desa Deah Geulumpang, Gedung Evakuasi Desa Alue Deah Teungoh serta satu gedung khusus yang bernama gedung TDMRC-Tsunami \& Disarter Mitigation Research Centre di Ulheu lheu.

Gedung evakuasi vertikal tsunami merupakan upaya menghindari gelombang tsunami dengan cara naik ke tempat/lantai bangunan yang lebih tinggi dari ketinggian genangan tsunami.

Pada saat ini standar pembangunan di Indonesia belum memperhitungkan beban tsunami secara khusus, oleh karena itu perlu adanya tinjauan ulang terhadap gedung evakuasi yang sudah ada dengan menggunakan perhitungan beban gempa sesuai SNI yang digunakan saat ini yaitu SNI 1726:2002 dan untuk perhitungan beban tsunami digunakan standar FEMA P-646. Gayagaya tsunami yang ditinjau pada penelitian ini yaitu gaya hidrodinamis dan gaya debris. Tujuan dari penelitian ini 
merupakan pemodelan kembali gedung evakuasi Desa Lambung dengan bantuan aplikasi SAP2000.v20 untuk mendapatkan hasil dari gaya geser, dispalcement, dan simpangan antar lantai yang terjadi sesuai dengan SNI 1726:2012. Hasil dari identifikasi ini didapat nilai displacement terbesar arah $\mathrm{x}$ dan y akibat beban gempa adalah 0,016235 $\mathrm{m}$ dan 0,05852 $\mathrm{m}$, sedangkan displacement akibat beban tsunami terbesar arah $\mathrm{x}$ dan $\mathrm{y}$ adalah $0,00837 \mathrm{~m}$ dan 0,28836 $\mathrm{m}$. Dapat dilihat bahwa displacement terbesar akibat beban tsunami. Hasil dari simpangan antar lantai akibat beban gempa arah $\mathrm{x}=$ 0,022004 $\mathrm{m}$ lebih kecil daripada simpangan antar lantai akibat beban tsunami arah $\mathrm{x}=0,045881 \mathrm{~m}$, dan pada simpangan antar lantai akibat beban gempa arah $\mathrm{y}=$ 0,069065 m lebih kecil daripada simpangan antar lantai akibat beban tsunami arah $\mathrm{y}=0,781535 \mathrm{~m}$.

Hasil yang didapat dari simpangan antar lantai akibat beban gempa lebih kecil daripada simpangan antar lantai izin, jadi hasil yang didapat sesuai dengan SNI 1726-2012. Sedangkan hasil simpangan antar lantai akibat beban tsunami pada lantai 1 dan 2 lebih besar daripada simpangan antar lantai izin, jadi hasil yang didapat tidak sesuai dengan SNI 1726-2012 atau struktur gedung evakuasi Desa Lambung tidak aman terhadap simpangan antar lantai pada arah y akibat beban tsunami.

\section{Tinjauan Kepustakaan}

\subsection{Tsunami}

Tsunami berasal dari bahasa Jepang yang berarti gelombang ombak lautan "tsu" berarti lautan, "nami" berarti gelombang ombak. Tsunami adalah serangkaian gelombang ombak laut raksasa yang ditimbulkan oleh adanya pergeseran di dasar laut akibat gempa (BNPB No.8 Tahun 2011)[2].

\subsection{Kriteria Struktur}

Gedung evakuasi tsunami menjadi tempat yang aman untuk pengungsian sementara bagi masyarakat apabila terjadinya tsunami. Oleh karena itu, desain struktur diusahakan dapat menahan beban gempa dan tsunami yang mungkin terjadi.

Fraser (2012)[3] menyatakan bahwa struktur gedung evakuasi tsunami merupakan material beton betulang, karena beton bertulang lebih mampu menahan beban tsunami sesuai dengan kedalaman genangan yang diharapkan. Selain itu, desain gedung evakuasi ini diharapkan memiliki ruang yang terbuka pada bagian lantai bawah agar air dapat melewati gedung sehingga dapat mengurangi tekanan pada struktur bangunan (Lukkunaprasit, 2009)[4].

\subsection{Pembebanan Struktur}

\subsubsection{Beban mati}

Berdasarkan SNI 1727:2013[5], Beban mati adalah berat seluruh bahan konstruksi bangunan gedung yang terpasang, termasuk komponen arsitektural, komponen struktural dan komponen non-struktural serta peralatan layan terpasang lainnya. Dalam menentukan beban mati menggunakan berat bahan dan konstruksi yang sebenarnya, dengan ketentuan apabila berat bahan yang tidak jelas maka nilai yang digunakan harus disetujui oleh pihak yang berwenang.

\subsubsection{Beban hidup}

Beban hidup adalah beban yang diakibatkan oleh pengguna dan penghuni bangunan gedung atau stuktur lain yang tidak termasuk beban konstruksi (SNI 1727:2013). Besarnya beban hidup terdistribusi merata minimum ditentukan berdasarkan standar yang berlaku. Beban hidup tersebut mengalami reduksi beban sesuai dengan penggunaan bangunannya. Reduksi beban hidup didapatkan dari mengalikan nilai koefisien reduksi dengan beban hidup.

\subsubsection{Beban gempa}

Berdasarkan pedoman gempa yang berlaku di Indonesia yaitu Tata Cara Perancangan Gempa untuk Struktur Bangunan Gedung dan Non Gedung (SNI 17262012)[6] ketentuan umum bangunan dalam pengaruh gempa adalah sebagai berikut :

1. Faktor keutamaan dan kategori risiko struktur bangunan.

2. Koefisien situs dan parameter respon spektral

3. Parameter percepatan spektra desain

4. Spektrum respon desain

5. Sistem struktur penahan beban gempa

6. Gaya geser dasar

7. Simpangan antar lantai

\subsubsection{Beban tsunami}

Berdasarkan FEMA P646 (2012)[7] gaya-gaya yang terdapat pada beban tsunami meliputi:

1. Gaya hidrostatik

Gaya hidrostatik terjadi ketika air yang bergerak perlahan mengenai komponen struktur. Gaya hidrostatik ini biasanya penting untuk struktur-struktur yang panjang yang mana ketinggian air di satu sisi sangat berbeda dengan ketinggian air di sisi yang lainnya.

\section{Gaya apung}

Gaya apung ini akan menjadi pertimbangan yang penting untuk komponen yang memiliki ketahanan kecil, contohnya seperti; bangunan dengan rangka kayu yang ringan, ruang bawah tanah, tangki kosong yang berada di atas maupun bawah tanah, kolam renang, dan komponenkomponen yang didesain hanya mempertimbangkan gaya berat gravitasi saja.

\section{Gaya hidrodinamik}

Gaya hidrodinamik digunakan pada saat air mengalir disekeliling struktur bangunan. Gaya hidrodinamis ini dapat dihitung dengan persamaan sebagai berikut:

$F_{d}=$

$\frac{1}{2} \rho_{s} C_{d} B\left(h u^{2}\right)_{m a k}$

Keterangan : 
$\rho_{s}=$ massa jenis air tsunami (termasuk sedimen $)\left(1100 \mathrm{~kg} / \mathrm{m}^{3}\right)$

$\mathrm{Cd} \quad=$ koefisien seret

$\mathrm{B}=$ luasan struktur pada bidang normal arah aliran

$\mathrm{h} \quad=$ kedalaman aliran

$\mathrm{u} \quad=$ kecepatan aliran pada lokasi struktur

dimana,

$\left(h u^{2}\right)_{\text {maks }}=g R^{2}\left(0,125-0,235 \frac{z}{R}+0,11\left(\frac{z}{R}\right)^{2}\right)$

Keterangan :

$\mathrm{g} \quad=$ percepatan gravitasi

$\mathrm{R} \quad=$ ketinggian run-up desain

$\mathrm{Z} \quad=$ elevasi tanah pada dasar struktur

\section{Gaya impulsif}

Gaya impulsif disebabkan oleh gelombang air terdepan yang menabrak struktur.

5. Gaya tumbukan debris

Gaya tumbukan yang berasal hayutan puing-puing dapat menjadi penyebab kerusakan pada bangunan. Gaya ini diasumsikan hanya bekerja pada salah satu bagian struktur bangunan pada ketinggian muka air. Gaya tumbukan oleh puing hanyutan ini dapat diperkirakan dengan menggunakan persamaan berikut :

$F_{i}=1,3 u_{\text {maks }} \sqrt{k m_{d}(1+c)}$

Keterangan :

Umaks = kecepatan maksimum aliran yang membawa puing dilokasi

$\mathrm{m} \quad=$ massa puing

$\mathrm{k} \quad=$ kekerasan puing

$\mathrm{c} \quad=$ koefisien masa hidrodinamik

6. Gaya tahanan debris

Gaya tahanan debris yang disebabakan dari akumulasi hanyutan puing-puing yang tersangkut pada struktur dapat dianggap sebagai gaya hidrodinamik tambahan oleh puing yang tertahan pada permukaan depan struktur.

\section{Gaya uplift}

Gaya angkat ini digunakan terhadap lantai bangunan yang terendam oleh genangan tsunami. Lantai bangunan yang terendam ini juga harus dirancang agar tahan terhadap gaya angkat berupa gaya apung dan hidrodinamik disamping desain standar untuk bebab gravitasi.

8. Beban Gravitasi Tambahan oleh Air yang Berada di Lantai Atas

Ketika genangan air telah mencapai lantai diatasnya, maka akan adanya tambahan beban gravitasi yang dapat melebihi kapasitas perencanaan gedung. Kedalaman air ini bergantung pada ketinggian maksimum rendaman tsunami dan kekuatan lateral dari dinding pada lantai tersebut.

Pada penelitian ini digunakan gaya hidrodinamik dan gaya tumbukan debris, karena kondisi bangunan pada daerah lambung merupakan struktur bangunan open building yang tidak memiliki dinding dan ketinggian air tsunami tidak melebihi ketinggian gedung itu sendiri sehingga gedung tidak terendam oleh genangan air tsunami, maka hanya dua gaya diatas yang dapat bekerja pada bangunan gedung evakuasi Desa Lambung.

\subsection{Kombinasi Pembebanan}

1. Menurut SNI 1726:2012 untuk kombinasi pembebanan gempa digunakan persamaan berikut ini:

$\mathrm{U}=1,4 \mathrm{D}$

$\mathrm{U}=1,2 \mathrm{D}+1,6 \mathrm{~L}$

$\mathrm{U}=\left(1,2+0,2 \mathrm{~S}_{\mathrm{DS}}\right) \mathrm{D}+1 \mathrm{~L} \pm 0,3\left(\rho \mathrm{Q}_{\mathrm{Ex}}\right) \pm$ $1\left(\rho \mathrm{QEy}_{\mathrm{E}}\right)$

$\mathrm{U}=\left(1,2+0,2 \mathrm{~S}_{\mathrm{DS}}\right) \mathrm{D}+1 \mathrm{~L} \pm 1\left(\rho \mathrm{Q}_{\mathrm{Ex}}\right) \pm$ $0,3\left(\rho\right.$ Q $\left.\mathrm{Ey}_{\text {Ey }}\right)$.

$\mathrm{U}=\left(0,9+0,2 \mathrm{~S}_{\mathrm{DS}}\right) \mathrm{D}+1,6 \mathrm{H} \pm 0,3\left(\rho \mathrm{Q}_{\mathrm{Ex}}\right) \pm$ $1\left(\rho \mathrm{Q}_{\mathrm{Ey}}\right)$

$\mathrm{U}=\left(0,9+0,2 \mathrm{~S}_{\mathrm{DS}}\right) \mathrm{D}+1,6 \mathrm{H} \pm 1\left(\rho \mathrm{Q}_{\mathrm{Ex}}\right) \pm$ $0,3\left(\rho \mathrm{Q}_{\mathrm{Ey}}\right)$

2. Menurut FEMA P-646 untuk kombinasi pembebanan tsunami digunakan persamaan berikut:

$\left.\mathrm{U}=1,2 \mathrm{D}+1,0 \mathrm{~T}_{\mathrm{S}}+1,0 \mathrm{~L}_{\mathrm{REF}}+0,25 \mathrm{~L} \ldots \ldots . .10\right)$

$\mathrm{U}=0,9 \mathrm{D}+1,0 \mathrm{TS}$

Keterangan :

$\mathrm{U}$ = beban ultimit;

D = beban mati;

L = beban hidup;

$\mathrm{H}$ = beban tanah;

$\mathrm{Q}_{\mathrm{Ex}}=$ beban gempa arah $\mathrm{x}$;

$\mathrm{Q}_{\mathrm{Ey}}=$ beban gempa arah $\mathrm{y}$.

$\mathrm{T}_{\mathrm{S}} \quad$ = beban tsunami (gaya hidrodinamik, dan gaya debris)

$\mathrm{L}_{\mathrm{REF}}=$ beban hidup untuk daerah yang terlindungi

\section{Metodologi Penelitian}

Objek pada penelitian ini adalah Gedung Evakuasi di Desa Lambung . Escape building ini dibangun pada tahun 2006 dengan luas 1.400 meter persegi dan degan ketinggian 14,64 meter dari dasar gedung, yaitu lantai 1 setinggi 6 meter, lantai 2 dan 3 setinggi masing-masing 4 meter, lantai 4 setinggi 0,64 meter. Gedung tersebut dibangun dengan jumlah kolom yang berbentuk lingkaran sebanyak 50 kolom.

\subsection{Data Teknis Bangunan}

Data teknis bangunan diperoleh dari pengukuran langsung dilapangan menggunakan meteran, laser, hammer test, dan bare detector. Dari pengukuran dilapangan di dapat hasil data berupa dimensi-dimensi struktur gedung dan jumlah tulangan pada kolom, balok, dan plat lantai.

\subsection{Data Gempa}

Data gempa yang digunakan merupakan rekaman gempa yang terjadi di patahan Sumatra - Andaman pada tanggal 26 Desember 2004 yang didapat dari USGS. Data gempa tersebut berupa akselorogram yang diubah menjadi respon spektrum dengan menggunakan bantuan aplikasi DADiSP/SE 6.7.

\subsection{Data Tsunami}

Data yang diperlukan untuk menghitung beban tsunami adalah kedalaman aliran tsunami pada tahun 2004 dan perbedaan elevasi tanah dasar bangunan yang 
didapatkan dari pemodelan penelitian Tursina (2019)[5]

yang dapat dilihat pada Gambar 1 berikut:

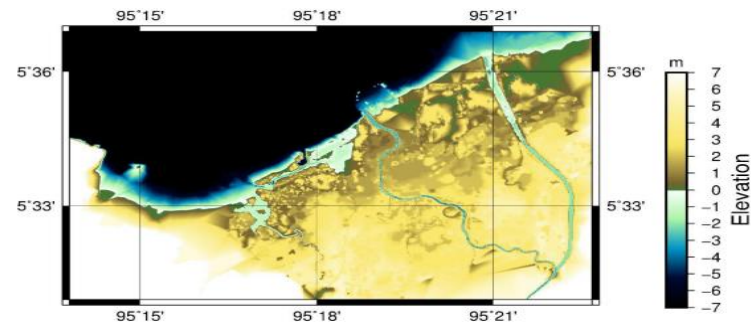

Gambar 1: perbedaan elevasi tanah dasar bangunan

Sumber : Tursina (2019)

\subsection{Pemodelan Struktur}

Pemodelan struktur dilakukan dengan bantuan aplikasi SAP2000.v20. tahap-tahap yang digunakan dalam pemodelan struktur sebagai berikut:

1. Pemodelan grid bangunan

2. Input mutu bahan

3. Pemodelan kolom

4. Pemodelan balok

5. Pemodelan plat lantai

6. Menentukan tipe tumpuan (restrain)

\section{Hasil dan Pembahasan}

Pemodelan struktur dilakukan dengan bantuan aplikasi SAP2000.v20. tahap-tahap yang digunakan dalam pemodelan struktur sebagai berikut:

- Tipe bangunan : Gedung Evakuasi

- Letak koordinat : (5³3'17.06”U), (95¹7'33.36”'T)

- Tahun konstruksi : Tahun 2006

- Jumlah lantai : 3 lantai

- Tinggi lantai 1 : 6 meter

- $\quad$ Tinggi lantai 2

$$
\text { dan } 3 \quad: 4 \text { meter }
$$

- Material : Reinforced Concrete $(R C)$

- $\quad$ Sistem rangka ruang : Frame

\subsection{Hasil Penelitian}

Hasil dari penelitian ini berupa hasil displacement dan simpangan antar lantai, serta hasil pemodelan gempa yang menggunakan data wavefrom gempa 2004 pada pemodelan struktur bangunan yang menggunakan software SAP2000.

\subsubsection{Hasil Data Gempa}

Untuk menganalisis perioda fundamental struktur (T) berdasarkan SNI-1726:2012, sebagai alternatif pada perhitungan struktur yang tidak melebihi 12 tingkat dimana sistem penahan gaya seismik terdiri dari rangka penahan momen beton secara keseluruhan dan tinggi tingkat paling sedikit $3 \mathrm{~m}$ :

Tabel 4. Periode fundamental alami

\begin{tabular}{clcc}
\hline OutputCase & StepType & StepNum & Period \\
\hline Text & Text & Unitless & Sec \\
\hline MODAL & Mode & 1 & 0,2670
\end{tabular}

\begin{tabular}{llcc} 
MODAL & Mode & 2 & 0,2151 \\
MODAL & Mode & 3 & 0,2035 \\
MODAL & Mode & 6 & 0,1314 \\
\hline OutputCase & StepType & StepNum & Period \\
\hline Text & Text & Unitless & Sec \\
\hline MODAL & Mode & 7 & 0,1070 \\
MODAL & Mode & 8 & 0,0840 \\
MODAL & Mode & 10 & 0,0671 \\
MODAL & Mode & 11 & 0,0354 \\
MODAL & Mode & 12 & 0,0319 \\
\hline
\end{tabular}

Dari hasil perhitungan, didapat :

$\mathrm{T}_{\mathrm{a}}$ syarat $=0,1 \mathrm{~N}$

$\mathrm{T}_{\mathrm{a}}$ syarat $=0,1(3)$

$\mathrm{T}_{\mathrm{a}}$ syarat $=0,3$

Hasil dari analisis SAP2000.v20 untuk periode fundamental alami Tc $=0,2670$ lebih kecil daripada ta yang disyaratkan. Maka hasil sesuai dengan SNI 1726:2012.

Tabel 5. Hasil analisis modal

\begin{tabular}{ccccc}
\hline OutputCase & ItemType & Item & Static & Dynamic \\
\hline Text & Text & Text & Percent & Percent \\
\hline MODAL & Acceleration & UX & 100 & 98,9744 \\
MODAL & Acceleration & UY & 100 & 99,017 \\
MODAL & Acceleration & UZ & 8,0737 & 0,5437 \\
\hline
\end{tabular}

Dari hasil modal load participation ratio, didapat dynamic percent untuk arah UX dan UY tidak kurang dari $90 \%$ menunjukkan bahwa nilai yang didapat memenuhi standar SNI-1726:2012 yaitu faktor partisipasi massa ragam efektif minimum sebesar $90 \%$.

Tabel 6. Hasil perhitungan massa dan berat

\begin{tabular}{ccc}
\hline GroupName & SelfMass & SelfWeight \\
\hline Text & $\mathrm{Kg}$ & $\mathrm{N}$ \\
\hline ALL & 1771373,36 & 17371239,39 \\
\hline
\end{tabular}

Perhitungan berat bangunan dilakukan dengan menjumlahkan beban mati yang bekerja pada masingmasing struktur lantai bangunan. Hal ini dilakukan dengan menghilangkan semua kolom diganti dengan gaya terpusat dimana kolom tersebut berada. Pada salah satu titik dipasang tumpuan jepit untuk mengetahui joint reaksi tiap lantai yang merupakan total berat dari tiap lantai yang bersangkutan.

Tabel 7. Gaya geser dasar

\begin{tabular}{cccc}
\hline OutputCase & Arah FX & Arah FY & Arah FZ \\
\hline Text & $\mathrm{N}$ & $\mathrm{N}$ & $\mathrm{N}$ \\
\hline Quake $\mathrm{x}$ & 11028444,76 & 889701,79 & 45752,34 \\
Quake $\mathrm{Y}$ & 588803,05 & 6846110,14 & 37379,69 \\
\hline
\end{tabular}

Gaya dasar seismik (V) dalam arah yang ditetapkan harus ditentukan berdasarkan persamaan 2.9 dan 2.10 pada bab II.

Koefisien respon seismik: 


$$
\begin{aligned}
\mathrm{C}_{\mathrm{s}} & =\frac{S D S}{\left(\frac{R}{I e}\right)} \\
\mathrm{C}_{\mathrm{s}} & =\frac{1,05}{\left(\frac{8}{1,5}\right)} \\
\mathrm{C}_{\mathrm{s}} & =0,197
\end{aligned}
$$

Berdasarkan perhitungan sebelumnya, berat seismik efektif (W) adalah 17371239,39 N. Sehingga gaya geser respon ragam, yaitu :

$$
\begin{aligned}
& \mathrm{V}=\mathrm{C}_{\mathrm{s}} \times \mathrm{W} \\
& \mathrm{V}=0,197 \times 17371239,39 \mathrm{~N} \\
& \mathrm{~V}=3422134,16 \mathrm{~N} \\
& 0,85 \mathrm{~V}=0,85 \times 3422134,16 \mathrm{~N} \\
& 0,85 \mathrm{~V}=2908814,04 \mathrm{~N}
\end{aligned}
$$

Dari hasil base reaction diperoleh nilai $\mathrm{V}$ lebih kecil dari $0,85 \mathrm{~V}_{1}$ yang mana tidak memenuhi SNI1726:2012. Oleh karena itu, diperlukan skala pembesaran.

Skala pembesaran $\operatorname{arah} \mathrm{x}=\frac{0,85 \mathrm{~V} 1}{V}=\frac{2908814,04}{11028444,76}=0,3$

Skala pembesaran arah $\mathrm{y}=\frac{0,85 \mathrm{~V} 1}{V}=\frac{2908814,04}{588803,05}=4,9$

Sehingga didapat gaya geser dasar hasil skala pembesaran yang dapat dilihat berikut:

Tabel 8. Gaya geser dasar hasil skala pembesaran

\begin{tabular}{cccc}
\hline OutputCase & Arah FX & Arah FY & Arah FZ \\
\hline Text & $\mathrm{N}$ & $\mathrm{N}$ & $\mathrm{N}$ \\
\hline Quake X & 2996859,99 & 241766,79 & 12432,7 \\
Quake Y & 2912015,09 & 33858479,5 & 184867 \\
\hline
\end{tabular}

\subsubsection{Hasil Perhitungan beban Tsunami}

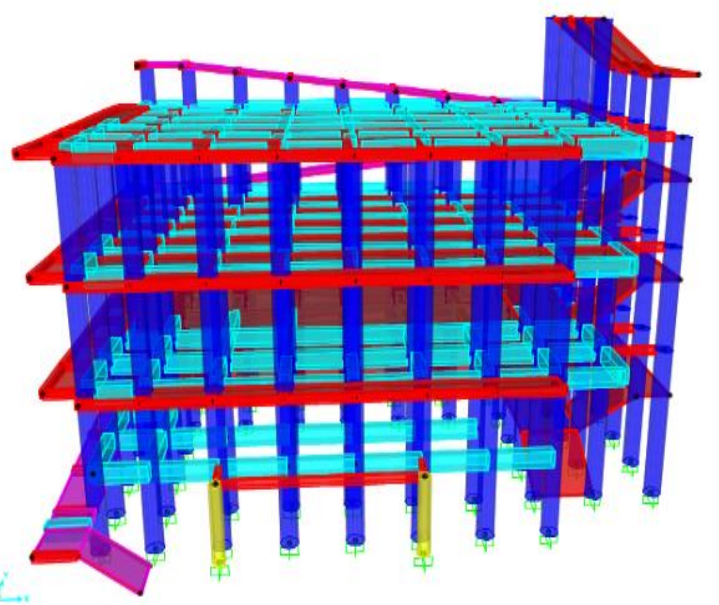

Gambar 2. Gedung evakuasi Desa Lambung hasil pemodelan SAP2000.v20

Struktur bangunan gedung evakuasi yang beralamat di Desa Lambung, Banda Aceh terletak \pm 500 meter dari bibir pantai. Beban tsunami yang diperhitungkan dalam desain struktur gedung evakuasi vertikal hanyalah gaya hidrodinamik dan gaya tumbukan debris berdasarkan FEMA P646 dengan perhitungan sebagai berikut.
Elevasi design runup height $(\mathrm{R})$
Elevasi $\pm 0,00$ gedung (z)

$$
=0,9 \text { meter }
$$$$
=4,76 \text { meter }
$$$$
=7,0 \text { meter }
$$
Percepatan gravitasi
$=9,81 \mathrm{~m} / \mathrm{det}^{2}$
Berat volume aliran tsunami $\left(\rho_{\mathrm{s}}\right)=1100 \mathrm{~kg} / \mathrm{m}^{3}$
$\mathrm{C}_{\mathrm{d}}$
$=2$

1. Gaya hidrodinamik

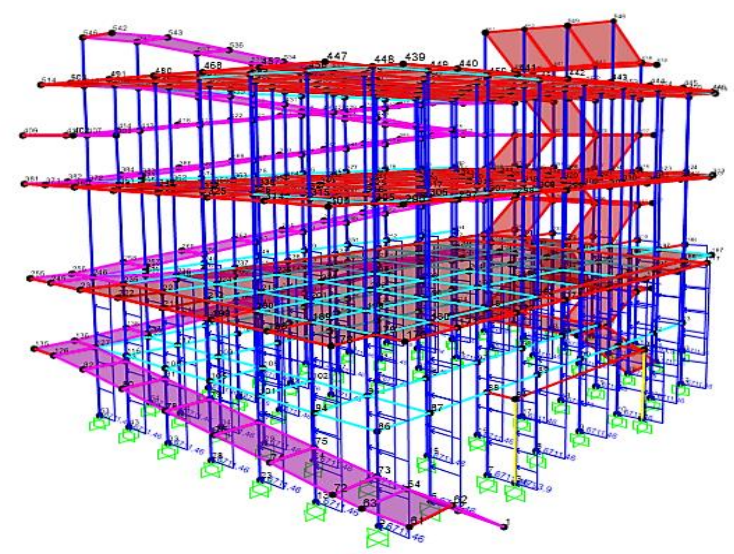

Gambar 3. Gaya hidrodinamik hasil pemodelan SAP2000.v20

$$
\begin{aligned}
& \left(h u^{2}\right)_{m a k s}=g R^{2}\left(0,125-0,235 \frac{Z}{R}+0,11\left(\frac{Z}{R}\right)^{2}\right) \\
& \left(h u^{2}\right)_{\text {maks }}=9,81 \times 7,9^{2}\left(0,125-0,235 \frac{0,9}{7,9}+0,11\left(\frac{0,9}{7,9}\right)^{2}\right) \\
& =61,013295 \mathrm{~m}^{3} / \mathrm{s}^{2} \\
& F_{d} \quad=\frac{1}{2} \rho_{s} C_{d} B\left(h u^{2}\right)_{m a k s} \\
& >\text { Kolom K1-70 } \\
& \text { Lebar kolom }(\mathrm{B})=0,7 \mathrm{~m} \\
& \mathrm{~F}_{\mathrm{d}} \quad=67,11 \mathrm{kN} / \mathrm{m} \text { ' } \\
& >\text { Kolom K2-50 } \\
& \text { Lebar kolom }(\mathrm{B})=0,5 \\
& \mathrm{~F}_{\mathrm{d}} \quad=47,93 \mathrm{kN} / \mathrm{m} \text { ' }
\end{aligned}
$$

2. Gaya tumbukan debris

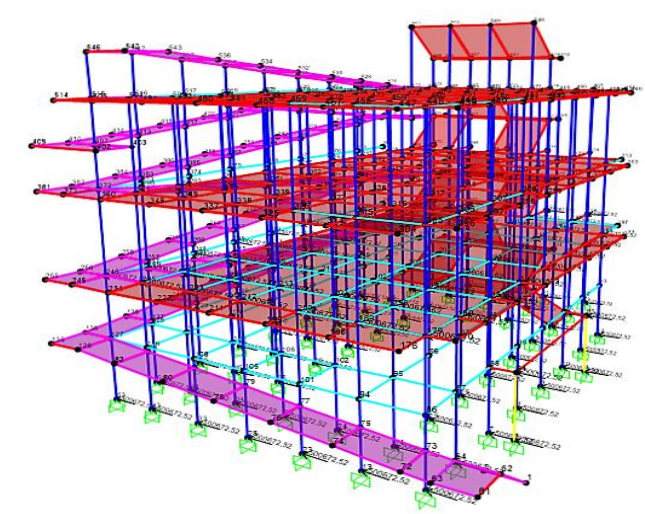

Gambar 4. Gaya tumbukan debris hasil pemodelan SAP2000.v20

Debris yang diperhitungkan dalam pemodelan struktur gedung evakuasi Desa Lambung, Banda Aceh ini yaitu batang kayu dengan data sebagai berikut berdasarkan FEMA P646: 
Tipe debris

: Lumber or Wood Log -

Massa oriented longitudinally

$\quad: 450 \mathrm{~kg}$

$\mathrm{C}_{\text {hidrodinamik }} \quad: 0$

K $: 2400000 \mathrm{~N} / \mathrm{m}$

$\mathrm{Umax}=\sqrt{\left(2 \cdot g \cdot R\left(1-\frac{z}{R}\right)\right)}$ $=\sqrt{\left(2 \times 9,81 \times 4,76\left(1-\frac{0,9}{7,9}\right)\right)}$ $=11,71921 \mathrm{~m} / \mathrm{s}$

$\mathrm{Fi} \quad=1,3 \operatorname{Umax} \sqrt{k m_{d}(1+c)}$ $=1,3 \times 11,71921 \sqrt{2400000 \times 450(1+0)}$ $=500672,5 \mathrm{kN}$

\subsubsection{Hasil Analisis Displacement dan} Simpangan Antar Lantai

Displacement terbesar yang diakibatkan oleh kombinasi beban gempa arah $\mathrm{x}$ dan $\mathrm{y}$ terjadi pada kombinasi 2, sedangkan displacement terbesar yang diakibatkan oleh kombinasi beban tsunami pada kombinasi 18.

Tabel 9. Displacement dan simpangan antar lantai

\begin{tabular}{cccccc}
\multicolumn{7}{c}{ akibat gempa arah x } \\
\hline Lantai & Tinggi & $\begin{array}{c}\text { Perpinda } \\
\text { han } \\
\text { Arah x }\end{array}$ & $\begin{array}{c}\text { Perpinda } \\
\text { han yang } \\
\text { di } \\
\text { perbesar }\end{array}$ & $\begin{array}{c}\text { Simpang } \\
\text { an antar } \\
\text { lantai }\end{array}$ & $\begin{array}{c}\text { Simpa } \\
\text { ngan } \\
\text { antar } \\
\text { lantai } \\
\text { izin }\end{array}$ \\
\hline & (m) & (m) & (m) & (m) & $(\mathrm{m})$ \\
\hline 4 & 14,64 & 0,016235 & 0,059528 & 0,009185 & 0,03 \\
3 & 14 & 0,01373 & 0,050343 & 0,014535 & 0,06 \\
2 & 10 & 0,009766 & 0,035809 & 0,022004 & 0,06 \\
1 & 6 & 0,003765 & 0,013805 & 0,013805 & 0,09 \\
\hline
\end{tabular}

Tabel 10. Displacement dan simpangan antar lantai

\begin{tabular}{cccccc}
\multicolumn{7}{c}{ akibat gempa arah y } \\
\hline Lantai & Tinggi & $\begin{array}{c}\text { Perpinda } \\
\text { han } \\
\text { Arah y }\end{array}$ & $\begin{array}{c}\text { Perpinda } \\
\text { han yang } \\
\text { di } \\
\text { perbesar }\end{array}$ & $\begin{array}{c}\text { Simpang } \\
\text { an antar } \\
\text { lantai }\end{array}$ & $\begin{array}{c}\text { Simpa } \\
\text { ngan } \\
\text { antar } \\
\text { lantai } \\
\text { izin }\end{array}$ \\
\hline & & & & & \\
\hline 4 & 14,64 & 0,05852 & 0,214573 & 0,036898 & 0,03 \\
3 & 14 & 0,048457 & 0,177676 & 0,060408 & 0,06 \\
2 & 10 & 0,031982 & 0,117267 & 0,069065 & 0,06 \\
1 & 6 & 0,013146 & 0,048202 & 0,048202 & 0,09 \\
\hline
\end{tabular}

Tabel 11. Displacement dan simpangan antar lantai akibat tsunami arah $x$

\begin{tabular}{cccccc}
\hline Lantai & Tinggi & $\begin{array}{c}\text { Perpinda } \\
\text { han } \\
\text { Arah } \mathrm{x}\end{array}$ & $\begin{array}{c}\text { Perpinda } \\
\text { han yang } \\
\text { di } \\
\text { perbesar }\end{array}$ & $\begin{array}{c}\text { Simpang } \\
\text { an antar } \\
\text { lantai }\end{array}$ & $\begin{array}{c}\text { Simpa } \\
\text { ngan } \\
\text { antar } \\
\text { lantai } \\
\text { izin }\end{array}$ \\
\hline & $(\mathrm{m})$ & $(\mathrm{m})$ & $(\mathrm{m})$ & $(\mathrm{m})$ & $(\mathrm{m})$ \\
\hline 4 & 14,64 & 0,00837 & 0,030690 & 0,001800 & 0,03 \\
\hline
\end{tabular}

\begin{tabular}{lccccc}
\hline 3 & 14 & 0,007879 & 0,028890 & 0,014520 & 0,06 \\
2 & 10 & 0,003919 & 0,014370 & 0,060251 & 0,06 \\
1 & 6 & 0,012513 & 0,045881 & 0,045881 & 0,09 \\
\hline
\end{tabular}

Tabel 12. Displacement dan simpangan antar lantai akibat tsunami arah y

\begin{tabular}{cccccc}
\hline Lantai & Tinggi & $\begin{array}{c}\text { Perpinda } \\
\text { han } \\
\text { Arah y }\end{array}$ & $\begin{array}{c}\text { Perpinda } \\
\text { han yang } \\
\text { di } \\
\text { perbesar }\end{array}$ & $\begin{array}{c}\text { Simpang } \\
\text { an antar } \\
\text { lantai }\end{array}$ & $\begin{array}{c}\text { Simpa } \\
\text { ngan } \\
\text { antar } \\
\text { lantai } \\
\text { izin }\end{array}$ \\
\hline & $(\mathrm{m})$ & $(\mathrm{m})$ & $(\mathrm{m})$ & $(\mathrm{m})$ & $(\mathrm{m})$ \\
\hline 4 & 14,64 & 0,28836 & 1,057320 & 0,018161 & 0,03 \\
3 & 14 & 0,283407 & 1,039159 & 0,040194 & 0,06 \\
2 & 10 & 0,272445 & 0,998965 & 0,217430 & 0,06 \\
1 & 6 & 0,213146 & 0,781535 & 0,781535 & 0,09 \\
\hline
\end{tabular}

\subsection{Pembahasan}

\subsubsection{Hasil analisis displacement beban gempa dan tsunami}

Berdasarkan hasil displacement dari beban gempa, maka displacement terbesar arah $\mathrm{x}$ dan $\mathrm{y}$ terdapat pada kombinasi 2, dari hasil SAP2000 v.20 didapat nilai displacement terbesar arah $\mathrm{x}$ adalah $0,016235 \mathrm{~m}$ pada titik 441 dan pada arah y sebesar $0,05852 \mathrm{~m}$ pada titik 441. Sedangkan dari beban tsunami displacement terbesar arah $\mathrm{x}$ dan $\mathrm{y}$ didapat pada kombinasi 18, dengan nilai displacement terbesar arah $\mathrm{x}$ adalah $0,00837 \mathrm{~m}$ pada titik 541 dan pada arah y sebesar $0,28836 \mathrm{~m}$ pada titik 541. Dapat dilihat bahwa displacement terbesar terjadi akibat beban tsunami.

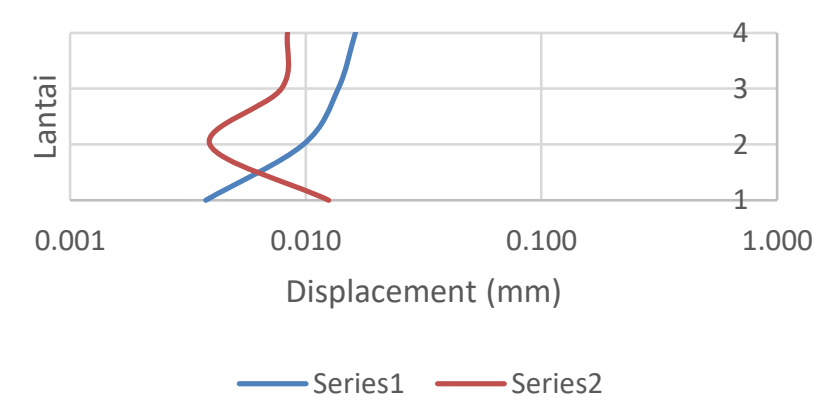

Gambar 5. Grafik displacement arah x akibat beban gempa dan tsunami

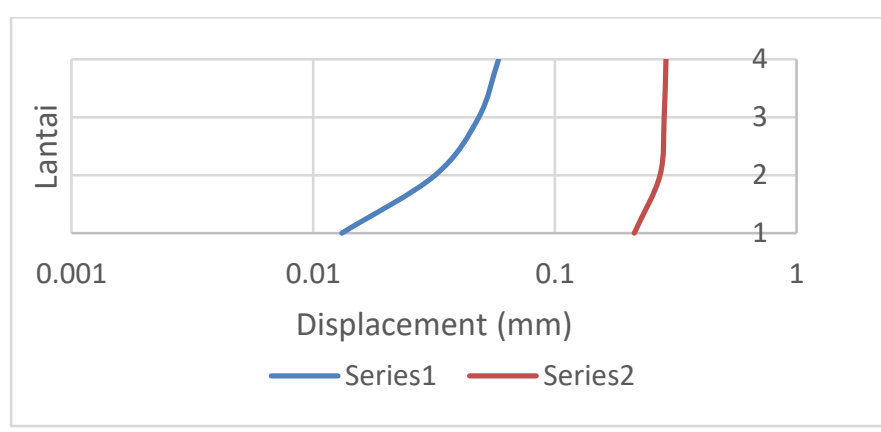

Gambar 6. Grafik displacement arah y akibat beban gempa dan tsunami

\subsubsection{Hasil analisis simpangan antar lantai beban gempa dan tsunami}


Dari Tabel 4.9 dan Tabel 4.11 didapat simpangan antar lantai arah $\mathrm{x}$ akibat beban gempa pada lantai 1 sebesar $0,013805 \mathrm{~m}$, lantai 2 sebesar $0,022004 \mathrm{~m}$, lantai 3 sebesar $0,014535 \mathrm{~m}$, dan lantai 4 sebesar $0,009185 \mathrm{~m}$. Sedangkan simpangan arah $\mathrm{x}$ akibat beban tsunami pada lantai 1 sebesar $0,045881 \mathrm{~m}$, lantai 2 sebesar $0,060251 \mathrm{~m}$, lantai 3 sebesar $0,014520 \mathrm{~m}$, dan lantai 4 sebesar $0,001800 \mathrm{~m}$. Dikarenakan hasil yang didapat lebih kecil daripada simpangan antar lantai yang diizinkan maka hasil yang didapat memenuhi SNI 17262012.

\section{Simpangan antar lantai arah $\mathrm{x}$}

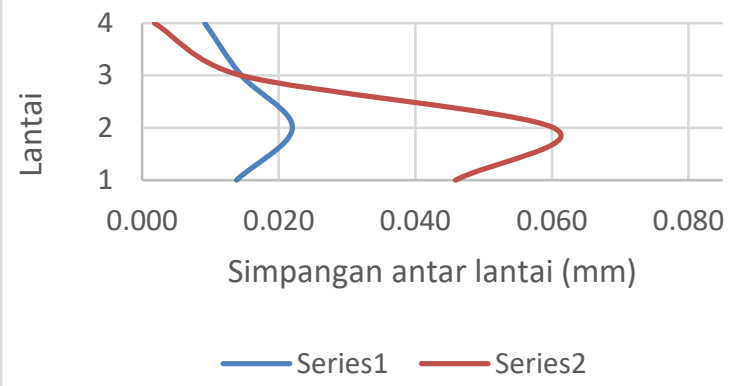

Gambar 4.6 grafik simpangan antar lantai arah $\mathrm{x}$ akibat beban gempa dan tsunami

\section{Simpangan antar lantai arah y}

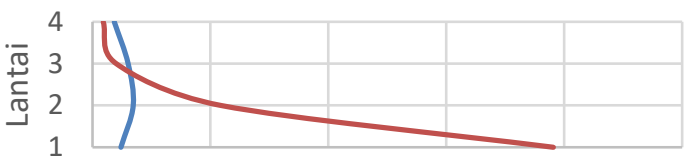

0.0000000.2000000.4000000.6000000.8000001.000000

simpangan antar lantai $(\mathrm{mm})$

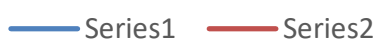

Gambar 4.7 grafik dsimpangan antar lantai arah y akibat beban gempa dan tsunami

Dari Tabel 4.10 dan Tabel 4.12 didapat simpangan antar lantai arah y akibat beban gempa pada lantai 1 sebesar $0,048202 \mathrm{~m}$, lantai 2 sebesar $0,069065 \mathrm{~m}$, lantai 3 sebesar 0,060408 , dan lantai 4 sebesar 0,036898 $\mathrm{m}$. Sedangkan simpangan arah y akibat beban tsunami pada lantai 1 sebesar $0,781535 \mathrm{~m}$, lantai 2 sebesar $0,217430 \mathrm{~m}$, lantai 3 sebesar 0,040194 m, dan lantai 4 sebesar $0,018161 \mathrm{~m}$.

\section{Kesimpulan}

1. Secara keseluruhan struktur gedung evakuasi Desa Lambung, Banda Aceh menurut perhitungan berdasarkan SNI 1726-2012 dan FEMA P646, termasuk gedung yang aman terhadap beban gempa dan tsunami.

2. Gedung evakuasi Desa Lambung aman terhadap beban gempa menurut SNI 1726-2012, akan tetapi tidak aman pada simpangan antar lantai izin menurut SNI 1726-2012 akibat beban tsunami.
3. Bangunan Gedung Evakuasi Tsunami Desa Lambung, Banda Aceh berdasarkan hasil modelling SAP 2000.v 20 memiliki nilai periode (Tc) 0,267021 pada mode 1 dan 0,42 pada mode 2. Dimana, berdasarkan SNI 1726-2012, $\mathrm{T}_{\mathrm{a}}<$ $\mathrm{T}_{\mathrm{c}}<\mathrm{C}_{\mathrm{u}} \times \mathrm{T}_{\mathrm{a}}$, digunakan $\mathrm{T}=\mathrm{T}_{\mathrm{c}}$ yaitu 0,267021 detik.

4. Hasil yang didapat dari simpangan antar lantai akibat beban gempa lebih kecil daripada simpangan antar lantai izin, jadi hasil yang didapat sesuai dengan SNI 1726-2012. Sedangkan hasil simpangan antar lantai akibat beban tsunami pada lantai 1 dan 2 lebih besar daripada simpangan antar lantai izin, jadi hasil yang didapat tidak sesuai dengan SNI 1726-2012 atau struktur gedung evakuasi Desa Lambung tidak aman terhadap simpangan antar lantai pada arah y akibat beban tsunami.

\section{Saran}

Pada penelitian selanjutnya dapat dilakukan variasi pemodelan gempa dan tsunami berdasarkan letak sumber patahan, kedalaman tsunami atau variasi lainnya untuk beban tsunami yang lebih banyak lagi. Mengingat potensi terjadinya gempa dan tsunami yang sangat besar di Aceh, maka disarankan agar bangunan-bangunan struktur selanjutnya yang akan dibangun selalu mempertimbangkan beban-beban yang berasal dari gempa dan tsunami. Pada penelitian selanjutnya dapat dilakukan evaluasi terhadap ragam bangunan lainnya di Aceh khususnya Banda Aceh dan sekitarnya terhadap kerentanan struktur pada bencana gempa dan tsunami.

\section{Daftar Pustaka}

[1] National Oceanic Atmospheric Administration (online)., $\quad$ oktober 2019 (https://www.bbc.com/indonesia/indonesia-45742383, diakses 17 juni 2019).

[2] Peraturan Kepala Badan Nasional Penanggulangan Bencana, Tentang Standardisasi Data Kebencanaan, Nomor 8, Tahun : 2011

[3] S. Fraser, G. S. Leonard, H.Murakami, dan I. Matsuo, Tsunami Vertical Evacuation Buildings-Lessons for International Preparedness Following the 2011 Great East Japan Tsunami, Journal of Disaster Research 7: 448, 2012.

[4] P. Lukkunaprasit, A. Ruangrassamee, dan N. Thanasisathit, Tsunami Loading On Buildings With Openings, Science of Tsunami Hazards, 28(5): , 303-310, 2009.

[5] Thursina dan Syamsidik, 2019, Reconstruction of the 2004 Tsunami Inundation Map in Banda Aceh Through Numerical Model and Its Validation with Post-Tsunami Survey Data.

[6] Badan Standarisasi Nasional. 2012. Standar Nasional Indonesia 1726-2012: Tata Cara Perencanaan Ketahanan Gempa untuk Struktur Bangunan Gedung dan Non Gedung. Badan Standarisasi Nasional: Jakarta.

[7] Federal Emergency Management Agency. 2012. Guidelines for Design of Structures for Vertical Evacuation from Tsunami Second Edition. Department of Homeland Security FEMA Mitigation Division: Washington D.C 
